\title{
Understanding Acehnese Proverbs and Their Relation to the Community Work Ethics
}

\author{
${ }^{* 1}$ Mursyidin, ${ }^{2}$ Rahmad Nuthihar, ${ }^{3}$ Wahdaniah, ${ }^{4}$ Herman RN \\ ${ }^{1}$ Universitas Malikussaleh, Lhokseumawe, Indonesia, Email: mursyidin.za@ unimal.ac.id \\ ${ }^{* 2}$ Akademi Komunitas Negeri Aceh Barat, Aceh Barat, Indonesia, Email: rahmad.nuthihar@aknacehbarat.ac.id \\ ${ }^{3}$ Politeknik Negeri Lhokseumawe, Aceh Barat, Indonesia, Email: wahdaniah@pnl.ac.id \\ ${ }^{4}$ Universitas Syiah Kuala, Banda Aceh, Indonesia, Email: herman13@gmail.com
}

Submitted: 22/04/2020 Revised: 12/05/2020 Accepted: 19/05/2020

How to cite this article: Mursyidin, M., Nuthihar, R., Wahdaniah, W., \& RN, H. (2020). Understanding Acehnese proverbs and their relation to the community work ethics. IJELR: International Journal of Education, Language, and Religion, 2(1), 11-16. http://doi.org/10.35308/ijelr.v2i1.2191

\begin{abstract}
This study discusses the work ethic of the Acehnese people based on hadih maja (Acehnese proverb). This type of research is qualitative with a qualitative descriptive approach. Sources of research data come from a collection of Aceh proverbs written by Hasyim, Cs and interviews with the community regarding the use of Aceh proverbs. The results of this study concluded that the work ethic of the people of Aceh can be reviewed based on five attitudes which include (1) responsibility, (2) hard work, (3) rational, (4) honest, and (5) discipline. The form of responsibility includes doing the job completely and not giving the job to someone else. Hard work is described by not wasting time but utilizing time productively. Rational attitude is described by doing logical work and being able to do well. Honesty must be carried out by workers in order to obtain safety in and trust from others. Furthermore, discipline is illustrated by the routine of the Acehnese people who demand to work on time.
\end{abstract}

Keywords

Acehnese proverb; work ethic; hadih maja; Aceh

\section{Introduction}

The Acehnese proverbs or also called hadih maja is used by the Acehnese people in social life, especially to refine meaning. Hadih maja is Aceh's oral poetry that is synonymous with traditional expressions or folk poetry (Mohd. Harun, 2006; Herman, Mukhlis, Saiful, \& Sanusi, 2018). In daily life, Acehnese proverbs are used to improve work ethic. This is due to Aceh being an area hit by armed conflict and tsunami. Meanwhile, poverty in Aceh is difficult to minimize as long as people's dependence on the government has not been abandoned in their lives (Maifizar, 2016). Therefore, the proverb of Aceh is one of the instruments for the people of Aceh in improving work ethic.

In carrying out daily activities, especially in doing something, there are a variety of Acehnese proverbs that mandate to be obeyed and shunned according to the allegory of the proverb. In general, the work ethic of the Acehnese people can be reviewed based on the Acehnese proverb, which describes the attitude of a worker that must be carried out. This Aceh Proverb requires every worker to do good in accordance with what is taught in Islam. 
Changing times have influenced the work ethic of the people of Aceh. This can be seen from the shift in the function of the coffee shop (warkop). The warkop has changed its function from a coffee place and an interaction room to a new workplace (Mursyidin, 2018; Mursyidin, Mauliansyah, Tjoetra, Saputra, \& Muhammad, 2019). The younger generation usually utilizes warkop as a new workplace by utilizing Wi-Fi facilities to carry out work.

The Acehnese proverbs raised in this study is a collection of proverbs written by Hasyim et al. As time went on, Acehnese proverbs were rarely used. That is because the younger generation never again listens to the Aceh proverbs. In fact, the Aceh proverb has three functions namely, first, a tool to convey various information on compaction, education, and structure. Second, the means of expression in various communication contexts to convey the intention of the speaker. Third, as a directive function (Mohammad Harun, Qismullah Yusuf, \& Karnafi, 2020; Mohd. Harun, 2006).

In doing something, a work ethic is needed to make work spirit and belief in a person or group. This work ethic can be influenced by various factors and one of the factors is attitude. Aceh, which is the foyer of Mecca, in daily life is guided by the Koran and hadith so that the Sufi value is very thick in the people of Aceh (Nutihar \& Luthfi, 2019).

There are various theories regarding work ethic and the dominant theories used to study work ethic are the 8 principles put forward by Jansen (2008). The eight principles include (1) work is worship, (2) work is a mandate, (3) work is a calling, (4) work is art, (5) work is honor, (6) work is actualization, (7) work is grace, and (8) work is service. In this regard, the Acehnese in carrying out their work strongly adhere to the demands taught in Islam.

Proverbs Aceh also has a magical power that is able to suggest human emotions or feelings. Most Acehnese proverbs use the word archaic to achieve aesthetic effects, besides showing that Acehnese proverbs have existed for a long time (Mohd Harun, 2009). In addition, in proverbs Aceh has a directive function which is stated in contrasting statements even though it is stated indirectly.

The use of Aceh proverbs is commonly used by parents to advise their children to behave in accordance with the mandate of the Aceh proverb. This is because the Aceh proverb is a literature that can be used by parents as a means of growing character as well as an introduction to the value of local wisdom (Sudigdo, 2018 p. 6). In addition, this Aceh proverb is important to teach children to be able to strike a balance between intellectual intelligence and moral intelligence. Students can be characterized and have a moral that is commendable, so that they will form intelligent and dignified humans (Parlindungan, Lisyati, \& Rahma, 2019; Pratiwi, 2018).

If in public Aceh proverbs are also used as a medium of entertainment where in the Aceh proverbs there are interesting diction and have aesthetic value in terms of sound. The most complex source of reading Acehnese proverbs is the book of Aceh Proverbs written by Hasyim (1977) with the original title Himponan Hadih Manja. Researchers' search results, a book that discusses the proverb of Aceh was also written by several authors, namely (Azwardi, 2017; Norman, 2017; Zulaini, 2019). The use of Aceh proverbs is also discussed in detail in Harun's (2009) book entitled Understanding the Acehnese.

The relation of Aceh's proverbs in this study is to describe the work ethic based on attitudes which include, (1) responsibility, (2) hard work, (3) rational, (4) honest, and (5) discipline. From each of these attitudes, the researcher tries to find the work ethic attitude as mandated in the Aceh proverb. Research on the work ethic of the Acehnese people in terms of Aceh proverbs has been done by Harun et al. (2015). 


\section{Method}

This research is categorized in qualitative research with a qualitative descriptive approach. Descriptive research focuses on the designation of meaning, description, clarification, and placement of data in their respective contexts and the data in the form of words (Mahsun, 2005). The data of this study were sourced from the Aceh proverbs written by Hasyim (1977). Data processing is done by stages (1) data selection, (2) data classification (3) analysts, and (4) drawing conclusions.

\section{Results and Discussion}

The results of this study examine the work ethic of the Acehnese community contained in the book collection of proverbs in Aceh Hasyim (1977) ${ }^{1}$ consisting of (1) discipline / on time, (2) responsibility, (3) hard work, (4) rational, and (5) ) honest. These five attitudes determine the outcome of a job so that attitude must be present in every job. The Aceh proverb which contains the five attitudes is as follows.

\section{Responsible}

Work ethic can be seen from the attitude in the form of responsibility. Responsible for doing a job is the main thing to determine the success of the job. In proverbs Aceh also describes how these responsibilities are carried out by workers. This can be observed in the data below.

\section{Data I}

'Oh Iheueh tapukat, jinoe tapiléh.

After being seized, it is now selected

Context Data I describe the work of fishermen who use trawlers when fishing in the sea. Catches of fish using trawlers will usually get a lot of fish and various types. As a result, many small fish are discarded because they are not sold in the market or rarely interested by buyers. The Aceh Proverb teaches the people of Aceh, especially the reader, to be responsible for doing something.

\section{Data II}

Soe nyang gatai nyan keuh nyang geumarö.

Who is itchy is what dissolves.

The meaning of data II above is the antonym of the Indonesian proverb, people eat jackfruit from other people who get the sap. The Aceh proverb analogizes who feels itchy skin, it is he who has to scratch. In the context of a work ethic, workers are often 'washing their hands' or relinquishing responsibility to others. In fact, the wrong mistake was him. In addition, the above proverb also teaches the reader that if asked to be willing to attend the invitation and if not invited do not need to attend a certain event.

\section{Hard work}

The people of Aceh have always been known as tenacious and diligent workers. Perseverance is seen by using every yard and vacant land for gardening or planting plants that produce fruit. The work ethic in the form of hard work contained in the proverb of Aceh is as follows.

\section{Data IV \\ Nibak taduek gèt tajak, meurumpok akai bicara. \\ Instead of sitting well walking, meeting common sense (mind)}

\footnotetext{
${ }^{1}$ Some of this data was taken from books Peribahasa Aceh published by the Aceh Regional Office of Education and Culture. 
The proverb of Aceh in data IV teaches the people of Aceh to always do positive and beneficial things for themselves and others. In the language explained that rather than sitting, it would be better to walk because it will add insight and other positive knowledge. Sitting on the data is displayed lazily or idle. If this continues to be done by workers will not bring any profit at all. Therefore, the work ethic outlined in the Aceh proverb is that Acehnese people are generally hard workers.

\author{
Data V \\ Bèk tatak ateueng bak padé masak. \\ Do not clean the embankment while cooking rice.
}

The Aceh proverb in data $\mathrm{V}$ urges the reader not to clean the rice field when the rice is yellowing. Clearing paddy fields when the rice has yellowed is in vain. That is because the harvest time for rice is near and cleaning the rice field should be done before the rice turns yellow. The Aceh Proverb teaches the people of Aceh, especially to the readers that hard work must be done at the right place and time.

\title{
Rational
}

Reviewed based on the Big Indonesian Dictionary (KBBI), rational is meaningful according to the mind and logical reasoning or according to a healthy mind and in accordance with reason (Kemdikbud, 2019). Rational attitude in work ethic is very important to be applied in daily life so that the target to be achieved in a job is truly realized. This is due to the work to be done without considering rationality which will adversely affect the work to be done until the end. The Aceh proverb that explains the attitude of work ethic in the form of rationality is as follows.

\section{Data VI}

Meung tan sabé teuneun deungon neudong, tabri mantong hana hareuga.

If it is not in harmony with the weaving, it will be worthless.

The rational attitude shown in data VII concerns the results of unfavorable weaving which is not given freely to others. Woven cloth is a very valuable and artistic item. However, if the woven product is not neat and harmonious, the item will be worthless and have no artistic value. In this case, the Aceh proverb teaches the people of Aceh, especially to readers, that doing something must have aesthetic and rational value. In other words, everything that is disorganized according to reason is not valued by people.

Data VII

Baranggapeue buet tameugurèe, baek tatirèe han sampóreuna.

Something we work to learn, do not imitate imperfect.

The Aceh Proverb in Data VII teaches the reader that to do something must be rationality by learning rather than merely imitating the work of others. Studying that is meant here is not neces sarily in formal education conducted at school but rather studying every work that will be done. The attitude of rationality in the form of learning from others will produce a perfect job, but conversely if just imitating the work will not be optimal or in other terms the job is done. This Aceh proverb is almost the same as the Indonesian proverb which is very absurdly teaching, like a flower does not happen.

\section{Honest}


Work ethic in the form of honesty is the main capital that must be owned by every worker in order to gain the trust of others. Honesty is the key to the success of workers. The Aceh proverb that explains the value of honesty at work can be observed in the data below.

\title{
Data VIII
}

Utang tabayeue, janji tapeutróh.

Debt paid, promise kept.

\author{
Data IX \\ Meunyö teupat niet deungon kasat, baranggapat han binasa. \\ If honest intentions and intentions, anywhere does not perish.
}

Data VIII on this proverb in Aceh demands an attitude of honesty of workers in daily life. The Aceh proverb said that the debt must be paid off and the promise must be kept. If the Aceh proverb is put into practice in life, the impact that will be felt will be very large. For example, someone who wants to open a business by borrowing capital from others. Furthermore, the meaning of the Aceh proverb in data IX is that a virtuous and honest person will survive wherever he is. The work ethic in the form of honesty is very decisive in one's success in carrying out business.

\section{Discipline}

Work ethic in the form of discipline is very important to be applied in carrying out the work. Discipline of the people of Aceh can be seen from the routine that starts from dawn towards night. For example, fishermen will wake up in the morning to go to sea and return to the mainland after the fish catch is satisfying. Discipline in carrying out the work really determines success. However, if the routine is not carried out properly, automatically the fishermen will not get maximum results. The Aceh proverb that explains the work ethic in the form of discipline is as follows.

\section{Data X}

Bak tatunyok bèk meu-iseuk bak tapeuduek beu meulabang.

On those who are appointed, do not miss, on what is placed so that they are fixed.

The proverb of Aceh in data X explains the discipline related to what was agreed upon from the start. What has been pointed out should not be missed and what has been placed so as not to shift. The purpose of the Aceh proverb is to teach the people of Aceh, especially the reader, that all actions must always be right on target. Or orders must be obeyed with full discipline.

\section{Conclusion}

The results of this study concluded that the work ethic of the people of Aceh contained in the Aceh proverb included (1) discipline / on time, (2) responsibility, (3) hard work, (4) rational, and (5) honest. The application of these five values is very important to support one's professionalism in workers. Likewise, job vacancies often require these five values because they are indicators of the success of a job. This study only examined the work ethic based on the five attitudes and did not fully describe the work ethic. It is recommended to improve this research by comprehensive and in-depth research related to the work ethic in addition to the five findings of this study.

\section{References}

Azwardi. (2017). Binatang dalam peribahasa Aceh. Jakarta: Badan Pengembangan dan Pembinaan 
Bahasa Kementerian Pendidikan dan Kebudayaan.

Harun, Mohammad, Qismullah Yusuf, Y., \& Karnafi, M. (2020). Figurative language used in a novel by arafat nur on the aceh conflict. Kasetsart Journal of Social Sciences, 41(2), 395-400.

https://doi.org/10.34044/j.kjss.2020.41.2.12

Harun, Mohd. (2006). Struktur, Fungsi, dan Nilai Hadih Maja: Kajian Puisi Lisan Aceh. Universitas Negeri Malang.

Harun, Mohd. (2009). Memahami Orang Aceh. Bandung: Citapustaka Media Perintis.

Herman, Mukhlis, Saiful, \& Sanusi. (2018). The Concepts of Prayer and Respect as Character Education of Acehnese Children. In Proceedings of the International Conference on the Roles of Parents in Shaping Children's Characters (ICECED) (pp. 450-457). Banda Aceh.

Jansen, S. (2008). 8 Etos Kerja Profesional. Jakarta: PT Malta Printindo.

M.K Hasyim. (1977). Peribahasa Aceh. Banda Aceh: Dinas Pendidikan dan Kebudayaan Daerah Aceh.

Mahsun. (2005). Metode Penelitian Bahasa. Jakarta: PT Raja Grafindo Persada.

Maifizar, A. (2016). Karakteristik dan Fenomena Kemiskinan Keluarga Miskin Pedesaan di Aceh. Community, 2(3), 298-314. https://doi.org/10.4135/9781849209403.n73

Mursyidin. (2018). Pergeseran pola interaksi warung kopi pada masyarakat aceh barat. Community, 4(2), 201-210.

Mursyidin, Mauliansyah, F., Tjoetra, A., Saputra, J., \& Muhammad, Z. (2019). The effectiveness of village budget used for Village's development, 19(19), 1158-1174.

Norman, I. (2017). Hadih maja: filosofi hidup orang aceh. Banda Aceh: Rumah Cendekia.

Nutihar, R., \& Luthfi. (2019). Nilai Sufistik dalam Lantunan Doa Karya Ricky Syahrani Sebagai Bahan Bacaan Anak. TAZKIR: Jurnal Penelitian Ilmu-Ilmu Sosial Dan Keislaman, 5(1), 97-106.

Parlindungan, F., Lisyati, L., \& Rahma, E. A. (2019). Uncovering Pretend-Play and Peer Culture among Kindergarten Children: A Developmental Perspective. IJELR: International Journal of Education, Language and Religion, 1(1), 1-6.

Sudigdo, A. (2018). Penumbuhan Budi Pekerti Berbasis Kearifan Lokal Melalui Pembelajaran Sastra Anak Di Sekolah Dasar. Bahastra, 38(1), 1. https://doi.org/10.26555/bahastra.v38i1.7627

Zulaini, L. (2019). Kata-kata inspirasi dan hadih maja bahasa Aceh. Bandung: Rumah Pena Pustaka. 